\title{
Pengaruh Pupuk Urea terhadap Produksi dan Pertumbuhan Rumput Odot (Pennisetum purpureum cv Mott )
}

\author{
The Effect of Urea Fertilizer on Production and Growth of Odot Grass (Pennisetum purpureum cv \\ Mott)
}

Joko Daryatmo*, Wida Wahidah Mubarokah dan Budiyanto

Politeknik Pembangunan Pertanian Yogyakarta-Magelang

Jl. Magelang-Kopeng Km 7 Purwosari Tegalrejo Magelang 56192

Article history

Accepted: September 23, 2019 ;

Approved: July 9, 2019

* Corresponding author:

E-mail:

jkdaryatmo@gmail.com

\section{Abstract}

The availability of forgae which is inadequate both in quantity and quality is one of the problems in livestrock growth. One attempt to ssolve the problem is to cultivate the superior grass that is able to produce high-quality ang high-yielding forages such as Odot grass (Pennisetum purpureum cv. Mott). This study aims to determine the effect of 4 doses of urea fertilizer on production and growth of Odot grass. The experimental design used was a one way ANOVA with 4 treatments and each treatment consisted of 5 replications. The treatment used is Control (P0), urea at a dose of $100 \mathrm{~kg} / \mathrm{ha}(\mathrm{P} 1)$, urea at a dose of $150 \mathrm{~kg} / \mathrm{ha}(\mathrm{P} 2)$, urea at a dose of $200 \mathrm{~kg} / \mathrm{ha}(\mathrm{P} 3)$. The parameters observed were number of tillers, stem length, leaf length, grass height and grass production. The results of statistical analysis showed that the treatment of urea fertilizer had no significant effect on plant height. The treatment of urea fertilizer had a significant effect $(\mathrm{P}<0.05)$ on number of tillers, stem length, leaf length and grass production. It can be concluded that the administration of urea fertilizer can increase the number of tillers, stem length, leaf length and odot grass production compared to odot grass that is not given urea fertilizer.

Keywords: Urea; Fertilizer; Growth; Production; Pennisetum purpureum cv Mott

\section{Pendahuluan}

Kementerian Pertanian telah menetapkan upaya khusus pencapaian swasembada pangan berkelanjutan yang terdiri dari tujuh komoditas yaitu padi, jagung, kedelai, tebu, bawang merah, cabai dan daging. Pencanangan program swasembada pangan di lingkup peternakan, dalam rangka mencapai ketahanan pangan nasional, dilaksanakan melalui program Upaya Khusus Sapi Indukan Wajib Bunting (UPSUS SIWAB), yang bertujuan untuk meningkatkan populasi dan memenuhi kebutuhan produk hewan dalam negeri. Untuk mendukung keberhasilan UPSUS SIWAB, maka dilaksanakan beberapa kegiatan pendukung antara lain: salah satunya adalah penyediaan hijauan pakan ternak yang bernutrisi tinggi.
Seiring dengan target peningkatan jumlah populasi dan produksi ternak ruminansia besar yang tinggi, kebutuhan pakan ternak merupakan faktor pendukung yang perlu diperhatikan, terutama dalam hal kebutuhan nutrisi. Pakan sapi yang baik adalah pakan yang terdiri dari hijauan berupa rumput segar, leguminosa dan konsentrat yang lengkap kandungan asam aminonya.

Salah satu permasalahan di lapangan saat ini adalah pemberian hijauan pakan ternak yang rendah akan kandungan nutrisi, yang disebabkan oleh kurang diperhatikannya teknis pemberian unsur hara terhadap tanaman hijauan pakan ternak tersebut. Ketersediaan hijauan pakan yang kurang memadai baik kuantitas maupun kualitasnya, menjadi salah satu masalah dalam usaha pengembangan peternakan, sehingga perlu adanya upaya 
untuk meningkatkan produktivitas dan kualitas hijauan secara berkelanjutan. Salah satu upaya yang perlu dilakukan adalah membudidayakan rumput unggul yang mampu menghasilkan hijauan yang berproduksi dan berkualitas tinggi seperti rumput Odot ( $P$. purpureum $c v$. Mott).

Guna mencapai produksi hijauan pada tingkat yang diinginkan, penggunaan pupuk dan perbaikan kesuburan tanah adalah strategi yang sangat diperlukan. Diperkirakan 60\% dari tanah pertanian memiliki kekurangan unsur hara (Cakmak, 2001). Nitrogen merupakan unsur hara yang digunakan dalam jumlah yang besar untuk sebagian besar tanaman tahunan (Huber dan Thompson, 2007), karena nitrogen (N) merupakan salah satu nutrisi yang paling membatasi produksi tanaman.

Rumput Odot merupakan salah satu jenis rumput yang sesuai untuk pakan ternak, karena memiliki beberapa keunggulan. Keunggulan dan kepraktisan rumput Odot menurut Solihat (2013) adalah bahwa dalam penggunaan rumput Odot, para peternak akan memperoleh efisiensi, yaitu dalam pembudidayaan, rumput Odot mudah tumbuh meski di bawah naungan. Efisiensi lain adalah dalam pemberian pakan hijauan dari rumput Odot untuk sapi dan domba sama-sama dapat mencapai $100 \%$ terdiri atas rumput Odot. Kelebihan lain yaitu peternak tidak perlu lagi menggunakan mesin pencacah (chopper) seperti yang selama ini digunakan untuk mengolah rumput Gajah (Solihat, 2013).

Sesuai uraian di atas, maka untuk meningkatkan produktivitas dan kualitas rumput Odot maka dilakukan penelitian pengaruh berbagai level pemupukan urea terhadap pertumbuhan dan produksi rumput Odot (P. purpureum cv. Mott).

\section{Materi dan Metode \\ Materi}

Penelitian ini dilaksanakan di lahan rumput kampus Politeknik Pembangunan Pertanian, Jurusan Peternakan Magelang, selama 2 bulan mulai bulan Januari 2019 sampai bulan Pebruari 2019. Alat-alat yang digunakan adalah: Cangkul, sabit, meteran, penggaris, timbangan, tali rafia, cutter, ember dan selang. Bahan yang digunakan adalah: Rumput Odot (P. purpureum cv. Mott), pupuk urea dan air.

\section{Metode}

Perlakuan yang diterapkan terdiri dari 4 perlakuan yaitu tanpa pupuk urea sebagai kontrol (P0), pemberian pupuk urea dengan dosis $100 \mathrm{~kg} / \mathrm{ha}(\mathrm{P} 1)$, pemberian pupuk urea dengan dosis $150 \mathrm{~kg} / \mathrm{ha}(\mathrm{P} 2)$, pemberian pupuk urea dengan dosis $200 \mathrm{~kg} / \mathrm{ha}$ (P3). Setiap perlakuan diulang 5 kali, sehingga lahan yang digunakan pada penelitian ini seluas $100 \mathrm{~m}^{2}$ dibagi menjadi 20 bedengan dengan ukuran masing-masing bedengan $2 \times 2,5 \mathrm{~m}^{2}$. Tiap bedengan ditanami rumput odot sebanyak 6 rumpun dengan jarak tanam $50 \times 50 \mathrm{~cm}$. Tiap rumpun diisi bibit sebanyak 3 stek. Pemupukan dilakukan setelah satu minggu penanaman.

Tahapan penelitian sebagai berikut: Pengumpulan data dengan cara pengukuran langsung pada tanaman meliputi jumlah anakan, panjang ruas, tinggi tanaman, panjang daun yang dilakukan satu kali setiap 2 minggu, serta produksi rumput segar dengan menimbang rumput yang telah dipanen menggunakan timbangan pada setiap kali defoliasi atau pemotongan. Pemotongan atau defoliasi pertama dilakukan saat umur tanaman 60 hari setelah tanam. Banyaknya jumlah anakan rumput odot diketahui dengan cara menghitung pertambahan jumlah anakan pada rumpun rumput odot. Penghitungan dilakukan dengan merata-rata jumlah anakan pada rumpun rumput odot dari tiap-tiap perlakuan. Penghitungan anakan rumput odot dilakukan empat kali yaitu pada Minggu ke-2 setelah penanaman, Minggu ke-4 setelah penanaman, Minggu ke- 6 setelah penanaman dan Minggu ke-8 setelah penanaman. Pertumbuhan rumput odot juga dilihat dari panjang ruas rumput odot. Panjang ruas diketahui dengan mengukur panjang ruas menggunakan alat ukur. Pengukuran dilakukan empat kali yaitu pada Minggu ke-2 setelah penanaman, Minggu ke-4 setelah penanaman, Minggu ke- 6 setelah penanaman, dan Minggu ke-8 setelah penanaman. Tinggi tanaman diketahui dengan mengukur tinggi tanaman menggunakan alat ukur (meteran). Pengukuran dilakukan empat kali yaitu pada Minggu ke-2 setelah penanaman, Minggu ke-4 setelah penanaman, Minggu ke-6 setelah penanaman dan Minggu ke- 8 setelah penanaman. Panjang daun diketahui dengan mengukur panjang 
daun menggunakan alat ukur. Pengukuran dilakukan empat kali yaitu pada Minggu ke-2 setelah penanaman, Minggu ke-4 setelah penanaman, Minggu ke- 6 setelah penanaman, dan Minggu ke-8 setelah penanaman.

\section{Analisis Data}

Data yang didapat, dianalisis menggunakan analisis variansi searah (Oneway ANOVA) (Sulaiman, 2002), menggunakan software SPSS. Selanjutnya apabila terdapat perbedaan maka dilanjutkan dengan uji Duncan pada taraf signifikansi 0,05 .

\section{Hasil dan Pembahasan \\ Pertumbuhan Rumput}

Secara umum, pertumbuhan rumput odot semakin meningkat dengan penambahan dosis pupuk urea. Rata-rata panjang ruas berkisar antara 12,70-17,30 cm. Panjang ruas rumput odot berbeda antar perlakuan $(\mathrm{P}<0,05)$. Berdasarkan Tabel 1 dapat diketahui bahwa rata-rata panjang ruas rumput odot terpanjang adalah pada perlakuan P3 (200 kg/ha) dengan rata-rata panjang ruas $17,30 \mathrm{~cm}$.

Tabel 1. menunjukkan rata-rata pertumbuhan rumput odot pada pemberian dosis pupuk urea yang berbeda.

Tabel 1. Rata-rata pertumbuhan rumput $P$. purpureum $c v$. Mott pada pemberian dosis pupuk urea yang berbeda

\begin{tabular}{lcccc}
\hline \multirow{2}{*}{\multicolumn{1}{c}{ Parameter }} & \multicolumn{4}{c}{ Perlakuan } \\
\cline { 2 - 5 } & P0 & P1 & P2 & P3 \\
\hline Panjang Ruas (cm) & $12,70^{\mathrm{a}}$ & $14,33^{\mathrm{b}}$ & $15,16^{\mathrm{b}}$ & $17,30^{\mathrm{c}}$ \\
Panjang Daun (cm) & $50,33^{\mathrm{a}}$ & $56,73^{\mathrm{b}}$ & $60,33^{\mathrm{b}}$ & $60,67^{\mathrm{b}}$ \\
Tinggi Tanaman (cm) ${ }^{\text {ns }}$ & 50,70 & 52,83 & 53,16 & 53,49 \\
Jumlah Anakan (batang) & $3,58^{\mathrm{b}}$ & $3,76^{\mathrm{b}}$ & $4,97^{\mathrm{a}}$ & $3,85^{\mathrm{b}}$ \\
\hline a, b, c Superskrip yang berbeda pada baris yang sama menunjukkan perbedaan yang nyata $(\mathrm{P}<0,05)$. P0=Tanpa Urea, \\
P1=Urea 100 kg/ha, P2=Urea 150 kg/ha, P3=Urea 200 kg/ha \\
${ }_{\text {ns Non Signifikan }}$
\end{tabular}

Rata-rata panjang daun rumput odot, berkisar antara 50,33-60,67 $\mathrm{cm}$. Panjang daun rumput odot berbeda antar perlakuan $(\mathrm{P}<0,05)$. Perlakuan pupuk urea memberikan pengaruh yang nyata terhadap panjang daun dibandingkan pada kontrol. Panjang daun tertinggi pada perlakuan P3 meskipun secara statistik tidak nyata dibandingkan perlakuan P1 dan P2 namun lebih tinggi secara nyata $(\mathrm{P}<0,05)$ dibanding $\mathrm{P} 0$. Panjang daun dipengaruhi oleh unsur nitrogen, sebab unsur nitrogen merupakan unsur utama pembentuk zat hijau daun yang berguna untuk kegiatan fotosintesis tanaman. Panjang daun ini mirip dengan hasil penelitian Sirait et al. (2015) yakni $56,5-59,9 \mathrm{~cm}$, berada pada kisaran hasil penelitian Lasamadi (2013) yang memperoleh 50,2-61,4 cm serta lebih tinggi dari hasil penelitian Rellam (2017) yang menghasilkan kisaran panjang daun antara 44,16-53,33 cm.

Rata-rata tinggi tanaman rumput odot hasil penelitian berkisar antara 50,70-53,49 cm. Tinggi tanaman tidak berbeda antar perlakuan $(\mathrm{P}>0,05)$. Rata-rata tinggi tanaman cenderung makin tinggi dengan pemberian level urea yang makin tinggi, namun demikian perlakuan urea memberikan pengaruh yang tidak nyata terhadap tinggi tanaman. Tinggi tanaman ini sama atau berada pada kisaran tinggi tanaman sesuai hasil penelitian Sirait et al. (2015) yang menghasilkan tinggi tanaman antara 36,8-80,7 $\mathrm{cm}$.

Rata-rata jumlah anakan tanaman rumput odot berkisar antara 3,58-4,97 batang. Jumlah anakan tanaman rumput odot pada perlakuan P2 berbeda nyata dengan perlakuan lain dengan jumlah anakan sebanyak 4,97 buah $(\mathrm{P}<0,05)$. Hal ini menunjukkan bahwa pemberian dosis pupuk urea sebanyak 150 $\mathrm{kg} / \mathrm{ha}$ memberikan pengaruh yang paling baik untuk pertumbuhan jumlah anakan. Didukung oleh Purbajanti (2013) yang menyatakan pembentukan anakan tanaman akan meningkat seiring dengan penambahan bahan organik berupa hara. Pada fase pertumbuhan vegetatif tanaman membutuhkan hara untuk pembangun jaringan meristem, terutama $\mathrm{C}$ dan $\mathrm{N}$ (Purbajanti, 2013). Sependapat dengan 
Soepardi (1987), yang menyatakan bahwa meningkatkan ketersediaan unsur hara dalam tanah akan mengakibatkan pertumbuhan akar lebih baik, sehingga penyerapan unsur hara juga akan lebih banyak dan memenuhi kebutuhan tanaman.

\section{Produksi Rumput}

Secara umum, peningkatan produksi segar rumput odot semakin meningkat dengan penambahan dosis pupuk urea. Rata-rata poduksi segar rumput odot berkisar antara 4,17-6,12 kg/rumpun. Produksi segar rumput odot berbeda antar perlakuan $(\mathrm{P}<0,05)$. Pemberian pupuk urea dengan dosis $200 \mathrm{~kg} / \mathrm{ha}$ memberikan produksi segar tertinggi $(6,12$ $\mathrm{kg} / \mathrm{rumpun}$ ). Hasil produksi rumput pada penelitian ini kecuali pada P0 dan P1, lebih tinggi dibandingkan produksi rumput pada penelitian Paat dan Taulu (2012) yakni 4,69 kg per rumpun tanaman.

Tabel 2. Rata-rata produksi rumput $P$. purpureum $c v$. Mott pada pemberian dosis pupuk urea yang berbeda

\begin{tabular}{|c|c|c|c|c|}
\hline \multirow{2}{*}{ Parameter } & \multicolumn{4}{|c|}{ Perlakuan } \\
\hline & P0 & P1 & $\mathbf{P 2}$ & P3 \\
\hline Produksi (kg)/rumpun & $4,17^{\mathrm{a}}$ & $4,64^{\mathrm{b}}$ & $5,07^{\mathrm{c}}$ & $6,12^{d}$ \\
\hline
\end{tabular}

Hasil penelitian ini sesuai dengan Adijaya et al. (2007) yang melaporkan bahwa pemberian 1,7 liter/ha pupuk cair untuk rumput raja pada lahan kering masam mampu memberikan pertumbuhan dan produksi rumput raja tertinggi dibandingkan dengan tanpa pemupukan. Hal ini sependapat dengan Purbajanti (2013) yang menyatakan bahwa pemupukan dapat memberikan produksi bobot segar suatu tanaman menjadi lebih tinggi. Sesuai juga dengan pendapat Soepardi (1987), yang menyatakan bahwa meningkatkan ketersediaan unsur hara dalam tanah akan mengakibatkan pertumbuhan akar lebih baik, sehingga penyerapan unsur hara juga akan lebih banyak dan memenuhi kebutuhan tanaman. Rata-rata jumlah produksi rumput $P$. purpureum cv. Mott pada tiap-tiap perlakuan terdapat pada Tabel 2

\section{Kesimpulan}

Dapat disimpulkan bahwa pemberian pupuk urea hingga $200 \mathrm{~kg} / \mathrm{ha}$ mampu meningkatkan pertumbuhan dan produksi rumput Odot.

\section{Daftar Pustaka}

Adijaya, N., I.M. Rai Yasa dan S. Guntoro. 2007. Pemanfaatan Bio Urine dalam produksi hijauan pakan ternak rumput gajah. Prosiding Seminar Nasional Percepatan Transformasi Teknologi Pertanian untuk Mendukung Pembangunan
Wilayah. Balai Besar Pengkajian dan Pengembangan Teknologi Pertanian bekerjasama dengan Balai Pengkajian Teknologi Pertanian Bali.

Cakmak, I. 2001. Plant nutrition research: Priorities to meet human needs for food in sustainable ways. In: Plant nutrition: Food security and sustainability of agroecosystems, W. J. Horst, M. K. Schenk, A. Burkert, et al., Eds., 4-7. Dordrecht: Kluwer Academic.

Huber, D. M. and I. A. Thompson. 2007. Nitrogen and plant disease. In: Mineral nutritionand plant disease, L. E. Datnoff, W. H. Elmer, and D. M. Huber, Eds., 3144. St. Paul, MN: The American Phytopathological.

Lasamadi. R. D. 2013. Pertumbuhan dan Perkembangan Pennisetum purpureum $\mathrm{Cv}$. Mott yang Diberi Pupuk Organik Hasil Fermentasi EM4. Jurnal Zootek 32 (5): 158-171.

Paat, P. C. dan L. A. Taulu. 2012. Introduksi Tanaman Pakan Unggul Pennisetum purpureum Schum cv. Mott di Sentra Produksi Sapi Potong di Sulut. Seminar Nasional Teknologi Peternakan: 384-392.

Purbajanti, E. D. 2013. Rumput dan Legum: Sebagai Hijauan Makanan Ternak. Graha Ilmu. Yogyakarta.

Rellam, C. R. 2017. Pengaruh Naungan dan Pemupukan Nitrogen Terhadap 
Karakteristik Morfologis Rumput Gajah Dwarf (Pennisetum purpureum cv. Mott). Jurnal Zootek 37(1): 179-185.

Sirait, J., A. Tarigan dan K. Simanihuruk. 2015. Karakteristik Morfologi Rumput Gajah Kerdil (Pennisetum purpureum cv. Mott) pada Jarak Tanam Berbeda di Dua Agroekosistem di Sumatera Utara. Prosiding Seminar Nasional Teknologi Peternakan: $643-649$.
Soepardi, G. 1987. Sifat dan Ciri Tanah. Institut Pertanian Bogor. Bogor.

Solihat, K. 2013. Budidaya Rumput Odot. Harian Pikiran Rakyat, Bandung Jawa Barat. Diakses tanggal 20 November 2013. http://epaper.pikiranrakyat.com/index.php/component/flippingb ook/book/1713-rabu-17-juli-2013/61juli.html. 